\title{
Propagation studies in Smilax fluminensis Steud. (Smilacaceae)
}

\author{
Estudos de propagação em Smilax fluminensis Steud. (Smilacaceae)
}

\section{Anielca Nascimento Soares ${ }^{\mathrm{I}}$ Ana Dionísia da Luz Coelho Novembre ${ }^{\mathrm{II}}$ Aline Redondo Martins ${ }^{\mathrm{I}}$ Sônia Maria de Stefano Piedade ${ }^{\mathrm{III}}$ Beatriz Appezzato-da-Glória ${ }^{\mathrm{I}}$}

\begin{abstract}
Smilax L. species, popularly known in Brazil as salsaparrilha, have been used in folk medicine as tonic against rheumatism and as anti-syphilitic since the sixteenth century; however, until today, their roots have been explored in an extractive way. The aim of this study was to analyze the propagation of Smilax fluminensis aiming to meet the demand and to propose procedures for its sustainable management. It was analyzed the percentage of seed germination, rooting of aerial and subterranean stem cuttings and plant resprouting capacity after removal of the shoots. The monitoring lasted one year. Seeds were subjected to temperatures: $25^{\circ} \mathrm{C}, 30^{\circ} \mathrm{C}, 20$ $30^{\circ} \mathrm{C}$ and $20-35^{\circ} \mathrm{C}$ under a daily photoperiod of eight hours and in the absence of light. For rooting the stem cuttings, aerial and subterranean stems about $20 \mathrm{~cm}$ long with two nodal regions were subjected to treatment with distilled water (control) and indolbutyric acid (IBA) at 100ppm. The best germination percentages obtained for $\boldsymbol{S}$. fluminensis were $80 \%$ at $20-30^{\circ} \mathrm{C}$ under light and $85 \%$ at $30^{\circ} \mathrm{C}$ in the dark. Only subterranean stem cuttings showed significant difference concerning fresh and dry matter of roots with higher values in treatments with hormone compared to the control.
\end{abstract}

Key words: cuttings, greenbrier, resprouting, seed germination

\section{RESUMO}

As espécies do gênero Smilax L., conhecidas popularmente como salsaparrilha, são empregadas na medicina popular como fortificante contra o reumatismo e antissifilítico desde o século $X V I$, porém até hoje as suas raizes são exploradas de maneira extrativista. O objetivo deste estudo foi analisar a propagação de Smilax fluminensis visando a auxiliar no atendimento da demanda e apontar propostas para o seu manejo sustentável. Foram analisados a porcentagem de germinação de sementes, o enraizamento de estacas de ramos aéreos e subterrâneos e o acompanhamento ao longo de um ano da capacidade de rebrotamento das plantas após a retirada dos ramos aéreos. As sementes foram submetidas às temperaturas: $25,30,20-30$ e $20-35^{\circ} \mathrm{C}$, sob fotoperíodo diário de oito horas e na ausência de luz. Para o enraizamento de estacas, foram utilizados ramos aéreos e subterrâneos com aproximadamente $20 \mathrm{~cm}$ com duas regiões nodais submetidas ao tratamento com água destilada (controle) e com ácido indolbutírico (AIB) a $100 \mathrm{ppm}$. As melhores porcentagens de germinação obtidas para S. fluminensis, $80 \%$ em $20-30^{\circ} \mathrm{C}$ no claro e $85 \%$ a $30^{\circ} \mathrm{C}$ no escuro. Apenas as estacas de ramos subterrâneos enraizaram, houve diferença significativa em relação à massa fresca e seca de raizes com valores maiores nos tratamentos com hormônio em relação ao controle.

Palavras-chave: estacas, salsaparrilha, rebrotamento, germinação de sementes

\section{INTRODUCTION}

Propagation of medicinal species is of great importance, because as cultivation is increased, extraction is discouraged, thereby promoting the sustainable management of these species (MARONI et al., 2006). There are few research studies on methods of cultivation of medicinal plants (BITENCOURT et al., 2009). Smilax L. species, popularly known in Brazil as salsaparrilha, have been used in folk medicine as tonic against

'Departamento de Ciências Biológicas, Escola Superior de Agricultura Luiz de Queiroz (ESALQ), Universidade de São Paulo (USP), 13418-900, Piracicaba, SP, Brasil. E-mail: bagloria @esalq.usp.br. *Autor para correspondência.

"Departamento de Produção Vegetal, ESALQ, USP, Piracicaba, SP, Brasil.

IIIDepartamento de Ciências Exatas, ESALQ, USP, Piracicaba, SP, Brasil. 
rheumatism and as anti-syphilitic since the sixteenth century (PIRES, 1984). The most common substances found in the genus are flavonoids, phenolic acids (XU et al., 2005) and saponins (SHU et al., 2004). The use of roots and even until today the process of collecting them is through extraction, studies on their propagation have become necessary.

There are no studies on rooting of cuttings in Smilax species, but regarding seed germination there are few species studied and the tested variables are very distinct making it difficult to establish a comparative analysis of responses (HOLM, 1890; ANDREATA \& PEREIRA, 1990; SANTOS et al., 2003; PALHARES et al., 2009; MARTINS, 2009).

Smilax fluminensis Steud. was chosen for the study because presents a wide geographical distribution (ANDREATA, 1997), high capacity to form shoots in field and primary branches underground. Therefore, it is a promising species for cultivation to meet the demand from the pharmaceutical industry and to propose sustainable management practices of this species in areas of natural occurrence as a form of species conservation. The aim of this study was to analyze the seed germination rate, rooting of cuttings of aerial and underground branches and to monitor over a year the resprouting capacity of plants after removal of the aerial shoots.

\section{MATERIAL AND METHODS}

Seed collection: Ripe fruits of Smilax fluminensis Steud. were collected randomly aiming to gather the largest possible number of individuals within each population, thus, ensuring genetic variability. Fruits were collected in April 2008 in Itirapina, Assis, Franca, Anhembi, all located in the state of São Paulo. After natural drying of fruits, seeds were extracted manually.

Seed germination: To assess germinability seeds were evaluated at constant temperatures of $25^{\circ} \mathrm{C}$ and $30^{\circ} \mathrm{C}$ and alternate temperatures ranging from 20 $30^{\circ} \mathrm{C}$ and $20-35^{\circ} \mathrm{C}$ under dark conditions and light exposure with a photoperiod of eight hours, being the light provided by white fluorescent light bulbs, what supplied an irradiance of $40.32 \mu \mathrm{mol} \mathrm{m} \mathrm{m}^{-2} \mathrm{~s}^{-1}$. Petri dishes were inserted inside a colorless gerbox container for the experiments in light and a black gerbox container for those in the dark. The seeds under dark condition were monitored with a green safety light (AMARAL-BAROLI $\&$ TAKAKI, 2001). For the germination test, it was used plastic boxes ( $11 \mathrm{~cm}$ long and $3 \mathrm{~cm}$ high) containing $292 \mathrm{~g}$ of sterilized sand as substrate, moistened with $45 \mathrm{ml}$ of water, representing $60 \%$ of the water retention capacity by the sand. For each combination of temperature and light, four replicates of 25 seeds were sown. The germination was evaluated at intervals of seven days, recording normal and abnormal seedlings and nongerminated seeds (BRASIL, 2009). The ratings were calculated based on percentages of normal seedlings (germination)(MAGUIRE, 1962).

Tetrazolium test: At the end of the experiment, all non-germinated seeds from each temperature were evaluated regardless of whether light or dark condition. They were sectioned longitudinally to verify the presence or absence of the embryo. The seeds in which a normalappearing embryo was observed were submitted to tetrazolium test (BRASIL, 2009) to determine their viability. In that test, immediately following the longitudinal section, the seeds were placed into a small plastic cup containing $1 \%$ tetrazolium and kept at $30^{\circ} \mathrm{C}$ for 24 hours, then the seeds are classified in viable and non viable seeds. Besides seeds viability, it was also determined the embryoless seeds and those infected by fungi.

Rooting of stem cuttings: the collection of aerial and subterranean branches from adult plants of S. fluminensis took place in May 2008 at the Ecological Station Itirapina-SP as described in the next item. The samples was identified and incorporated into the Herbarium ESA under number 107633. Fifty stem cuttings of about $20 \mathrm{~cm}$ long with two nodal regions deriving from aerial and subterranean branches were made. Twenty-five cuttings were treated with distilled water (control) and the remainder with butyric acid (IBA) at 100ppm. The basis of cuttings was soaked overnight in the solution. Then, these cuttings were planted upright in plastic bags with sand, and taken to a greenhouse where they were irrigated manually every other day. One year after planting, the experiment was evaluated considering the following variables: percentage of rooted cuttings alive, percentage of dead cuttings, number of roots and shoots per cutting, number of leaves, length of the shoot and of the three largest roots, fresh and dry matter of roots. It was also performed free hand cuts of stem cuttings and carried out a reaction with Lugol to detect starch (BERLYN \& MIKSCHE, 1976).

Resprouting capacity in field: at the Ecological Station Itirapina-SP, five plots (areas) over a stretch that follows the riparian vegetation were selected. For each plot, four plants after removing the subterranean and aerial stems were monitored for over 12 months to assess their ability to resprout. Part of these stems was used to install the abovementioned experiment. Observations began in May 2008 and plants were monitored monthly regarding the number of new shoots formed, branch length and number of leaves on these new branches. Obtained results are illustrated in graph. 
Statistical design and analysis: for the experiment of rooting stem cuttings the statistical design was completely randomized with two treatments and five replicates made up of five stem cuttings. The statistical design for the germination experiment was completely randomized with four temperatures and two ligth conditons $(2 \times 4)$. The data were submitted to analysis of variance (ANOVA) and the means were compared by Tukey's test, at $5 \%$ probability using the SAS Statistical Analysis System scientific package (SAS Institute, 2001).

\section{RESULTS AND DISCUSSION}

The seed germination was monitored weekly since the installation of the experiment totaling 30 weeks. Germination was recorded after the third week of the experiment based on the issuance of the shoot, because the seeds were germinated in sand boxes. For all combinations of temperature and light studied no significant difference of germination between light and dark was found, that is, light did not interfere with the germination rate (neutral photoblastic). Results indicated that there were no significant differences between the alternating temperature between $20-30^{\circ} \mathrm{C}$ and constant temperatures at 25 and $30^{\circ} \mathrm{C}$. The temperature $20-35^{\circ} \mathrm{C}$ differed significantly from the others showing a lower germination rate.

The percentage of germination recorded at the end of the experiment was $73 \%$ and $85 \%$ for treatment at $30^{\circ} \mathrm{C}$ light and dark, respectively; $65 \%$ for treatment at $25^{\circ} \mathrm{C} ; 80 \%$ and $66 \%$ for the treatment between $20-30^{\circ} \mathrm{C}$ and $24 \%$ and $33 \%$ for the treatment between $20-35^{\circ} \mathrm{C}$ (Table 1). In treatments at $30^{\circ} \mathrm{C}$ and $20-30^{\circ} \mathrm{C}$, most seeds that did not germinate accused the presence of fungi (Table 2). In the treatment at $20-35^{\circ} \mathrm{C}, 76$ seeds showed viability i.e., $38 \%$ of the seeds that had not germinated.

In the present study, seeds germinated 20 days after the experiment installation in both light and dark conditions, whereas for $S$. campestris germination occurred after 30 days (ROSA \& FERREIRA, 1999), for $\boldsymbol{S}$. rufescens, S. elastica, S. syphylitica, S. quinquenervia
Table 1 - Germination percentage for seeds of Smilax fluminensis Steud. under four temperatures associated with light and dark .

\begin{tabular}{lcc}
\hline Temperature & $\begin{array}{c}\text { Ligth } \\
\text { Germination }\end{array}$ & $\begin{array}{c}\text { Dark } \\
\text { Germination }\end{array}$ \\
\hline $25^{\circ} \mathrm{C}$ & $65 \mathrm{Aa}$ & $65 \mathrm{Aa}$ \\
$30^{\circ} \mathrm{C}$ & $73 \mathrm{Aa}$ & $85 \mathrm{Aa}$ \\
$20-30^{\circ} \mathrm{C}$ & $80 \mathrm{Aa}$ & $66 \mathrm{Aa}$ \\
$20-35^{\circ} \mathrm{C}$ & $24 \mathrm{Ab}$ & $33 \mathrm{Ab}$ \\
\hline
\end{tabular}

Average followed by the same capital letter for light condition (data in line) and by the same lower-case letter for temperature (data in column) does not differ statistically at $\mathrm{P}=0.05$.

and $S$. syringoides germination ranged from 39-93 days (ANDREATA \& PEREIRA, 1990), for Smilax oblongifolia 40-100 days (PALHARES et al., 2009) and S. campestris, $S$. cissoides, $S$. brasiliensis and $S$. polyantha ranged between 22 and 36 days (MARTINS, 2009). According to POGGE \& BEARCE (1989) the increase in light intensity can reduce the time to start germination, which was also verified for $\boldsymbol{S}$. brasiliensis (MARTINS, 2009); however in this study exposure to light did not affect the germination start of $\boldsymbol{S}$. fluminensis.

The presence or absence of light was not a critical factor on the germination rate for S. fluminensis (Table 1) as well as for $\boldsymbol{S}$. campestris, $\boldsymbol{S}$. cissoides and $\boldsymbol{S}$. polyantha (MARTINS, 2009); however, ROSA \& FERREIRA (1999) observed that for $\boldsymbol{S}$. campestris, the highest rate of germination occurred in the darkness. Nevertheless, POGGE \& BEARCE (1989) reported that species found in more open areas such as $\boldsymbol{S}$. glauca require higher light intensity to germinate than those occurring in more shaded environments such as $\boldsymbol{S}$. rotundifolia. The authors assume that luminosity appears to be a limiting factor for germination of $\boldsymbol{S}$. rotundifolia.

The best germination rates obtained for $S$. fluminensis were $80 \%$ at temperatures between $20-30^{\circ} \mathrm{C}$ under light exposure and $85 \%$ at $30^{\circ} \mathrm{C}$ in the dark are

Table 2 - Viability of seeds checked from the Tetrazolium test for each temperature regardless of whether light or dark condition after uninstalling the experiment of seeds germination of Smilax fluminensis Steud.. (V) Number of viable seeds not germinated; (E) Number of seeds with or without embryo that did not present pink color after the test; (FU) Number of seeds accusing the presence of fungi; (Ge) Number of germinated seeds.

\begin{tabular}{|c|c|c|c|c|c|c|c|c|c|c|c|c|c|c|c|c|}
\hline & \multicolumn{4}{|c|}{25} & \multicolumn{4}{|c|}{30} & \multicolumn{4}{|c|}{$20-35$} & \multicolumn{4}{|c|}{$20-30$} \\
\hline & $\mathrm{V}$ & $\mathrm{E}$ & $\mathrm{FU}$ & $\mathrm{Ge}$ & $\mathrm{V}$ & $E$ & $\mathrm{FU}$ & $\mathrm{Ge}$ & $\mathrm{V}$ & $\mathrm{E}$ & FU & $\mathrm{Ge}$ & $\mathrm{V}$ & $\mathrm{E}$ & $\mathrm{FU}$ & $\mathrm{Ge}$ \\
\hline Seed number & 30 & 12 & 28 & 130 & 5 & 2 & 35 & 158 & 76 & 8 & 59 & 57 & 4 & 5 & 45 & 146 \\
\hline
\end{tabular}


close to results obtained by MARTINS (2009), i.e., $82 \%$, $78 \%$ and $55 \%$, temperature between $20-30^{\circ} \mathrm{C}$ under light exposure for Smilax campestris and S. cissoides and in the darkness for $\boldsymbol{S}$. brasiliensis. ROSA \& FERREIRA (1999) observed that the highest germination rate of $S$. campestris was $71 \%$ under light exposure at $30^{\circ} \mathrm{C}$. According to POGGE \& BEARCE (1989), for $\boldsymbol{S}$. rotundifolia the germination rate was $95 \%$, and for $S$. glauca it was $82 \%$ at $22^{\circ} \mathrm{C}$.

Aerial stem cuttings did not root in the two treatments and after four months all cuttings were dead. In turn, subterranean stem cuttings, after a year of the experiment, showed no significant differences in treatments with and without IBA in terms of percentage of alive rooted cuttings (60\% and $56 \%$ respectively), percentage of dead cuttings ( $40 \%$ and $44 \%$ ), average length of the three largest roots $(17.4 \mathrm{~cm}$ and $18.8 \mathrm{~cm})$, average number of roots (6.8 and 6.2), average number of leaves (5.5 and 5.2), average number of shoots per rooted cutting (1.8 and 1.7) and shoot length (19.0 $\mathrm{cm}$ and $13.1 \mathrm{~cm}$ ). There was significant difference in relation to the fresh and dry matter of roots being higher values observed in treatments with IBA (16.7g e $1.8 \mathrm{~g}$, respectively) compared to the control (5.9 and $1.1 \mathrm{~g}$, respectively).

DE BONA et al. (2005) and BIASI \& COSTA (2003) reported that use of the IBA did not increase the number of rooted cuttings, however the use of auxin favored the root system, increasing the fresh and dry matter of roots, as evidenced in this work. AYANOGLU et al. (2002) studying Salvia indica observed that application of IBA did not increase the number of rooted cuttings. However, the authors still suggest the use of auxin at low concentrations, as used in this study (100ppm), because it provides better rooting due to the increase in the number of shoots and roots. MAYER et al. (2008) suggest a relationship between higher rooting rate and high carbohydrate content available. In $\boldsymbol{S}$. fluminensis was observed such correlation, because aerial stem cuttings that did not root presented small accumulation of starch grains, whereas this accumulation was significant in subterranean stem cuttings (Figure 1A and B).

Adventitious roots formation in Smilax fluminensis ratoons does not involve callus and does

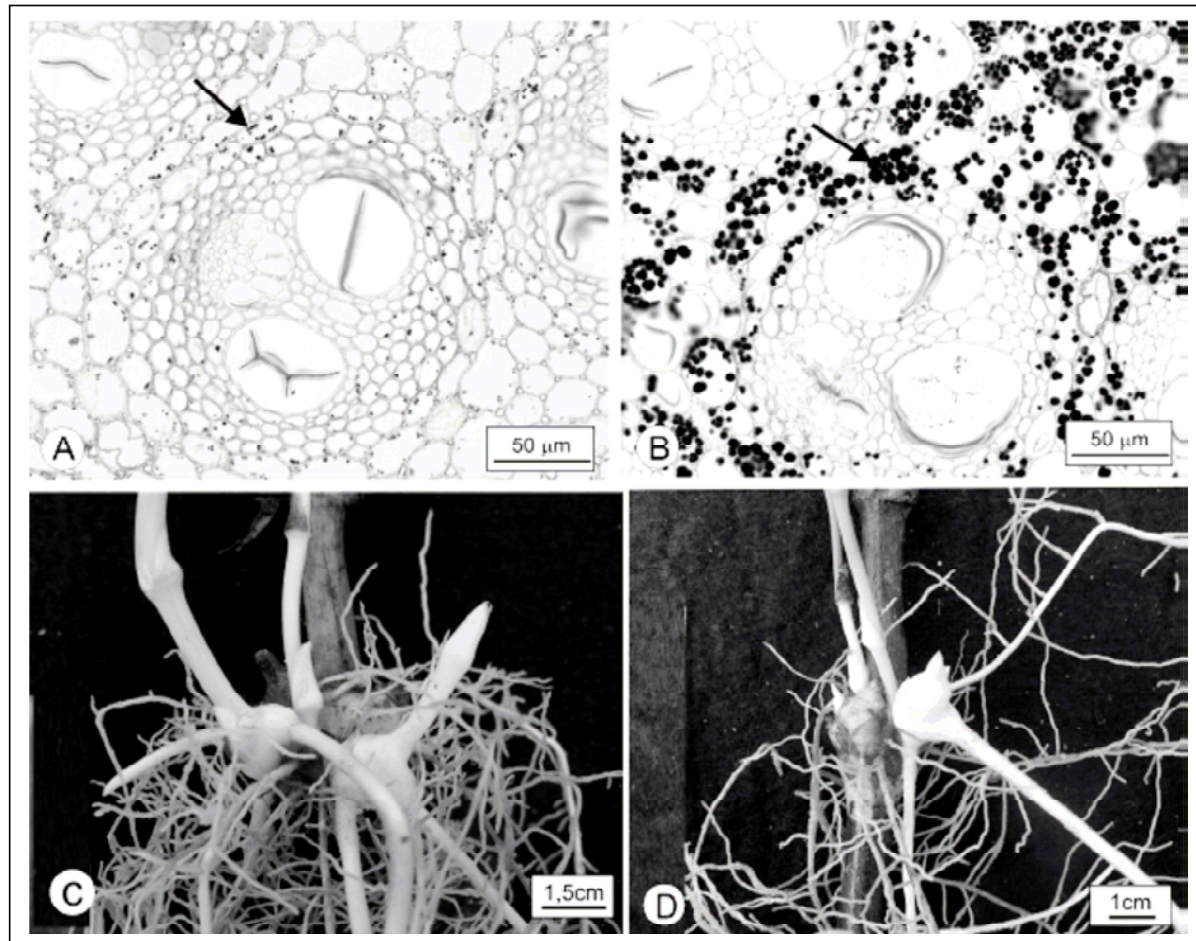

Figure 1 - Smilax fluminensis Steud. A-B. Transverse sections of aerial stem cuttings (A) and subterranean stem cuttings (B) subjected to the test with Lugol, indicating the presence of starch grains (arrows) in cells of the vascular cylinder. C-D. Rooted subterranean stem cuttings 12 months after of experiment installation. All adventitious root system is formed at the basal region of the swollen bud. 
not occur at the basal region, but after the swelling of the axillary bud. All adventitious root system is formed at the basal region of the swollen bud (Figure 1C and D) that remained shrouded by the substrate. These buds form new shoots which, in turn, may exhibit swollen axillary bud. The formation of roots associated with the swelling of axillary buds has been described for other species of the genus by MARTINS (2009).

In removing aerial stems and subterranean branches of plagiotrophycal distribution (Figure 2A) to confeccionate the cuttings (Figure 2B), it was always left a swollen nodal region (Figure $2 \mathrm{C}$ ). The resprouting of the plants began 30 days after the experiment installation evidenced by the development of new shoots (Figure
2D-F). At the end of the experiment all plants had new shoots of different sizes and stages of development. The largest branches were on average 1.80 meters long. Each plant formed 4.05 new shoots on average. The shoots development was evident from the $5^{\text {th }}$ month after experiment installation, i.e., in the favorable season for their development in the Brazilian Cerrado due to the increase in temperature and precipitation (Figure 3).

Resprouting in field as well as asexual propagation through cuttings have the advantage of maintaining the genetic characteristics of individuals and mitigating possible changes in the production of secondary metabolites that, according to MING (1994), is one of the biggest challenges for the cultivation and management of these medicinal species.

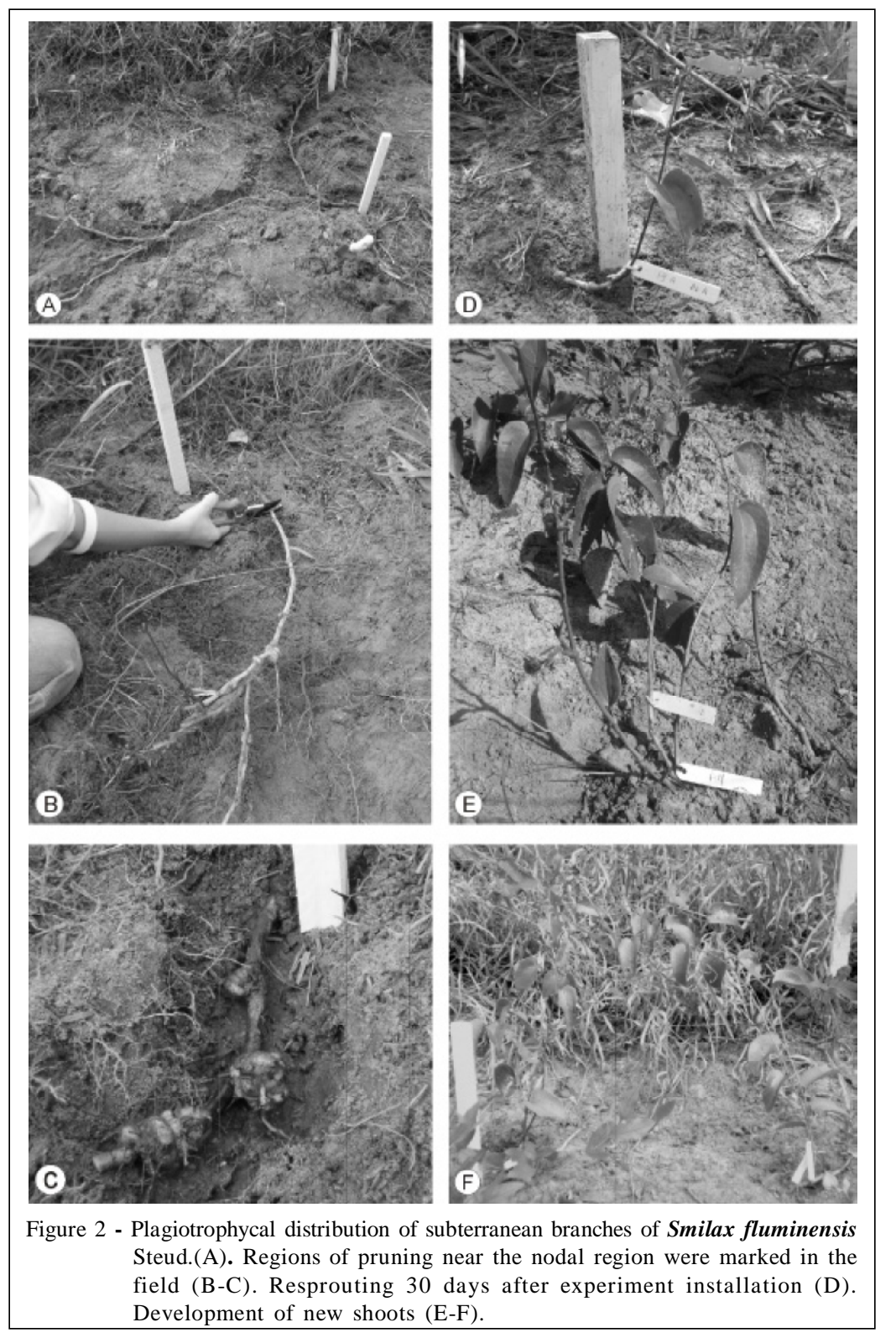

Ciência Rural, v.41, n.10, out, 2011. 


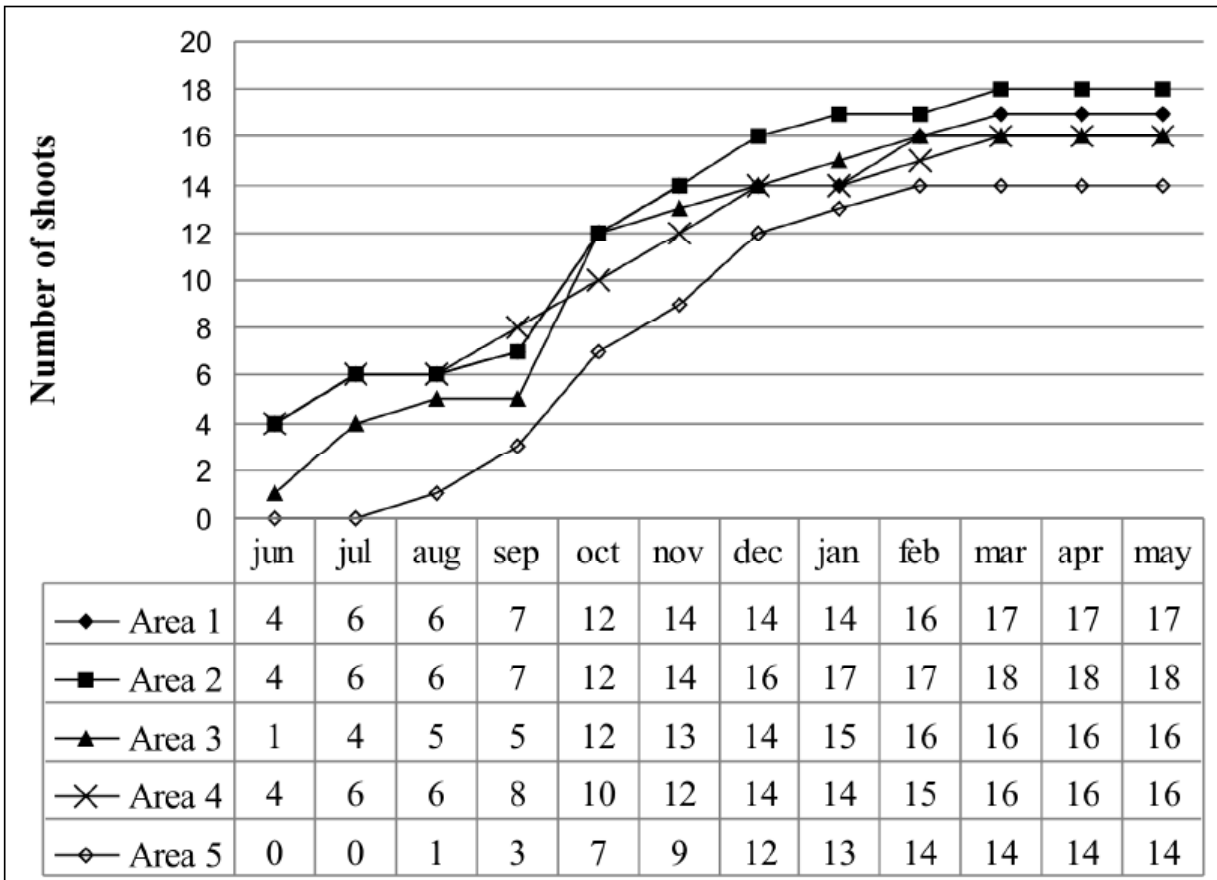

Figure 3 - Graph showing the number of new shoots per area from plagiotropic subterranean branches of Smilax fluminensis Steud. over 12 months.

\section{CONCLUSION}

The ability to propagate the species through the use of seeds and cuttings and shoots regeneration after removal of aerial stems in $\boldsymbol{S}$. fluminensis corroborates its potential for economic use in a sustainable manner, constituting an alternative to reduce the predatory extraction of native species.

\section{REFERENCES}

AMARAL-BAROLI, A.; TAKAKI, M. Phytochrome controls achene germination in Bidens pilosa L. (Asteraceae) by very low fluency response. Brazilian Archives of Biology and Technology, v.44, p.121-124, 2001. Available from: <http://www.scielo.br/ scielo.php?pid=1516-8913\&script=sci serial $>$. Accessed: Jan. $20^{\text {th }}$ 2011. doi: 10.1590/S1516-89132001000200002.

ANDREATA, R.H.P. Revisão das espécies brasileiras do gênero Smilax Linnaeus (Smilacaceae). Pesquisas-Botânica, v.47, p.7-244, 1997.

ANDREATA, R.H.P.; PEREIRA, T.S. Morfologia das plântulas de algumas espécies de Smilax L. Pesquisas-Botânica, v.41, p.7-24, 1990.

AYANOGLU, F. et al. Propagation of some native grown medicinal plants by stem cuttings. Journal of Herbs, Spices and Medicinal Plants, v.9, p.405-411, 2002. Available from: < h t t p : / / w w w. in form a wor $1 \mathrm{~d}$. c o m / s mp p / title $\sim$ content $=t 792306868>$. Accessed: Oct. $26^{\text {th }} 2010$.
BERLYN, G.P.; MIKSCHE, J.P. Botanical microtechnique and cytochemistry. Ames: Iowa State University, 1976. 336p.

BIASI, L.A.; COSTA, G. Propagação vegetativa de Lippia alba. Ciência Rural, v.33, p.455-459, 2003. Available from: <http:/ /www.scielo.br/scielo.php?pid=0103-8478\&script=sci serial $>$. Accessed: Jan. $20^{\text {th }} 2011$ doi: 10.1590/S010384782003000300010 .

BITENCOURT, J. et al. Rooting of "erva-mate" (Ilex paraguariensis A. St.-Hill.) cuttings from rejuvenated sprouts. Revista Brasileira de Plantas Medicinais, v.11, p.277-281, 2009. Available from: <http://www.ibb.unesp.br/servicos/ publicacoes/rbpm/pdf_v11_n3_2009/artigo8.pdf>. Accessed: Oct. $26^{\text {th }} 2010$.

BRASIL, Ministério da Agricultura, Pecuária e Abastecimento. Regras para análise de sementes. Brasília, 2009. Available from: <http:/ /www.bs.cca.ufsc.br/publicacoes/regras\%20analise\%20sementes.pdf>. Accessed: Oct. $26^{\text {th }} 2010$.

DE BONA, C.M. et al. Cutting propagation of Baccharis articulata (Lam.) Pers., Baccharis trimera (Less.) A.P. De Candolle e Baccharis stencephala Baker with auxins. Revista Brasileira Plantas Medicinais, v.7, p.26-31, 2005.

HOLM, T. Contributions to the knowledge of the germination of some North American Plants. Memories of Torrey Botanical Club, v.2, p.57-108, 1890.

MAGUIRE, J.D. Speed of germination-aid in selection and evaluation for seedling emergence and vigor. Crop Science, v.2, p.176-177, 1962.

Ciência Rural, v.41, n.10, out, 2011. 
MARONI, B.C. et al. Plantas medicinais do cerrado de Botucatu. São Paulo: Unesp, 2006. 194p.

MARTINS, A.R. Morfoanatomia, germinação e perfil químico de espécies de Smilax L. (Smilacaceae). 2009. 158f. Tese (Doutorado em Biologia Vegetal) - Instituto de Biologia, UNICAMP, Campinas, SP.

MAYER, J.L.S. et al. Root formation in cuttings of two species of Calliandra (Leguminosae - Mimosoideae). Rodriguésia, v.59, p.487-495, 2008. Available from: <http:// rodriguesia.jbrj.gov.br/rodrig59_3/006.pdf>. Accessed in: Oct. $26^{\text {th }} 2010$.

MING, L.C. Estudos e pesquisas de plantas medicinais na agronomia. Horticultura Brasileira, v.12, p.3-9, 1994.

PALHARES, D. et al. Studies on the seeds of Smilax goyazana A.Dc (Smilacaceae). Phyton, v.49, p.117-130, 2009.

PIRES, M.J.P. Aspectos históricos dos recursos genéticos de plantas medicinais. Rodriguésia, v.36, p.61-66, 1984.

POGGE, F.L.; BEARCE, B.C. Germinating common and cat greenbrier. Tree Planters' Notes, v.40, p.34-37, 1989.

ROSA, S.G.T.; FERREIRA, A.G. Germination of medicinal plant: Smilax campestris Griseb. (Salsaparrilha). Acta Horticultureae, v.502, p.105-111, 1999. Available from: <http://www.actahort.org/ books/502/502_14.htm>. Accessed: Oct. 26 $6^{\text {th }} 2010$.

SANTOS, M.R.A. et al. Estudos sobre superação de dormência em sementes de Smilax japecanga Grisebach. Ciência e Agrotecnologia, v.27, p.319-324, 2003. Available from: <http:/ /www.editora.ufla.br/site/_adm/upload/revista/27-22003_10.pdf.>. Accessed: Oct. 26 2010.

SAS INSTITUTE. SAS user's guide: statistics. Version 8.2. Cary, 2001. 1028p.

SHU, X. S. et al. Supercritical fluid extraction of saponins from tubers of Smilax china. Fitoterapia, v.75, p.656-661, 2004. Available from: $<\mathrm{h} \mathrm{t} \mathrm{t} \mathrm{p} \mathrm{:} \mathrm{/} \mathrm{/} \mathrm{w} \mathrm{w} \mathrm{w.} \mathrm{s} \mathrm{c} \mathrm{i} \mathrm{e} \mathrm{n} \mathrm{c} \mathrm{e} \mathrm{d} \mathrm{i} \mathrm{r} \mathrm{e} \mathrm{c} \mathrm{t} \mathrm{c} \mathrm{o} \mathrm{m/}$ science?_ob=MImg\&_imagekey=B6VSC-4D75SJR-1 $9 \&$ \& c di=6259\&_us er $=5674931 \&$ _pi i $=$ S 0367 $326 \times 04001522 \&$ _ origin = s e a c h \& _ cover Date=12\%2F01\%2F2004\&_sk=999249992\&view=c\&wchp=dGLzVtzzSkzS\&md5=a1f64dcb0fe6f30d8d9028afdbe6795a\&ie=/sdarticle.pdf $>$. Accessed: Jun. 20 ${ }^{\text {th }} 2009$. doi:10.1016/j.fitote.2004.06.011.

$\mathrm{XU}$, J. et al. Antiflammatory constituents from the roots of Smilax bockii Warb. Archives of Pharmacal Research, v.28, p.395-399, 2005. Available from: <http://apr.psk.or.kr/home/ journal/article_view.asp? articleuid $=\{284$ C5B0B-DC34-4326BB44-C28AF82413C2 $\}>$. Accessed: Oct. 26 2010. 